\title{
Changes in Parks and Green Spaces Ratio According to Land Ownership Processing Method in Urban Development
}

\author{
Sang Jo Lee ${ }^{1,2}$, Keun Young Huh ${ }^{2,3}$, and Jae Woo Chung ${ }^{2,4 *}$ \\ ${ }^{1}$ General Project Planning Office, Korea Land \& Housing Corporation, Jinju 52852, Korea \\ ${ }^{2}$ Department of Urban System Engineering, Gyeongnam National University of Science and Technology, Jinju 52725, Korea \\ ${ }^{3}$ Department of Landscape Architecture, Gyeongnam National University of Science and Technology, Jinju 52725, Korea \\ ${ }^{4}$ Department of Environmental Engineering, Gyeongnam National University of Science and Technology, Jinju 52725, Korea
}

\begin{abstract}
The purpose of this study was to analyze land use plans of 61 residential complexes and identify the factors that caused the variation of urban parks and green space ratio depending on the land ownership processing method. The ratio of urban parks and green space of expropriation districts was higher than that of replotting districts. Within the same city and country as well as other regions, the parks and green space ratio of land expropriation districts increased higher than $7 \%$ compared to that of replotting districts. The variation of urban parks and green space ratio was mainly related to the ratio of road. Small housing complexes such as detached house and quasiresidential sites resulted to expand space for road construction, thus, the areas of urban parks or green space came to reduce. The average urban parks and green space ratio in the urban development by the expropriation method and replotting method are $24.5 \%$ and $16.8 \%$ respectively. In order to prevent the reduction of urban parks and green space ratio according to the preference of detached house sites or quasi-residential sites in development zones, it is necessary to make systematic adjustment such as adjusting the urban parks and green space ratio securing standard.
\end{abstract}

Keywords: detached house, expropriation, quasi-residential site, ratio of road, replotting district

\section{Introduction}

Parks and green space in urban have not only aesthetic functions, but also other important functions for improving the health and welfare of residents such as providing leisure activities and opportunities for relaxation and reducing heat island effect. In addition, parks and green space purify atmospheric air, reduce air pollution, and protect wild birds or insects, and play a significant role in providing bases for symbiosis with natural ecosystems (Moon, 2001).

The Korean government enacted the Act on Urban Parks, Green Areas, Etc. in 2005 for the purpose of creating pleasant urban environments to secure healthy cultural urban life and promote public welfare, and under the Act, those who establish a development plan of a certain size or bigger need to secure urban parks and green space in their plan.

Housing development for creating urban housing complexes is mainly subject to laws such as the Housing Site 
Development Promotion Act, the Urban Development Act, and the Special Act on Public Housing. However, standards for parks and green space ratio vary by act, and, thus, even within one region, the ratio can vary depending on law applied. According to the report on the status of urban planning published by the Ministry of Land, Infrastructure and Transport in 2017, the per capita area of urban parks has continuously increased from $5.0 \mathrm{~m}^{2}$ in 2000 to $9.6 \mathrm{~m}^{2}$ in 2017 ever since the enactment of the Act on Urban Parks, Green Areas, Etc. By city and province, that in Sejong $\left(87.4 \mathrm{~m}^{2}\right)$, Jeonnam $\left(17.9 \mathrm{~m}^{2}\right)$ and Jeonbuk $\left(13.1 \mathrm{~m}^{2}\right)$ was high, while that in Daegu $\left(4.9 \mathrm{~m}^{2}\right)$, Jeju $\left(5.4 \mathrm{~m}^{2}\right)$ and Gwangju $\left(6.1 \mathrm{~m}^{2}\right)$ was lower than the national average. In addition, the area of urban parks significantly depended on city and province.

Housing development for creating urban housing complexes is mainly subject to laws such as the Housing Site Development Promotion Act, the Urban Development Act, and the Special Act on Public Housing. However, standards for parks and green space ratio vary by act, and, thus, even within one region, the ratio can vary depending on law applied. According to the report on the status of urban planning published by the Ministry of Land, Infrastructure and Transport in 2017, the per capita area of urban parks has continuously increased from $5.0 \mathrm{~m}^{2}$ in 2000 to $9.6 \mathrm{~m}^{2}$ in 2017 ever since the enactment of the Act on Urban Parks, Green Areas, Etc. By city and province, that in Sejong $\left(87.4 \mathrm{~m}^{2}\right)$, Jeonnam $\left(17.9 \mathrm{~m}^{2}\right)$ and Jeonbuk $\left(13.1 \mathrm{~m}^{2}\right)$ was high, while that in Daegu $\left(4.9 \mathrm{~m}^{2}\right)$, Jeju $\left(5.4 \mathrm{~m}^{2}\right)$ and Gwangju $\left(6.1 \mathrm{~m}^{2}\right)$ was lower than the national average. In addition, the area of urban parks significantly depended on city and province.

Urban development projects for creating urban housing complexes can be implemented using a method of expropriation or replotting or by combining both the methods (Article 21 (1) of the Urban Development Act). In the expropriation method, a project operator forcibly expropriates the entire land within the project district, extinguishes previous rights and operates the project with his or her new rights (Lee, 2005). In the replotting method, urban development is executed by altering the blocks, form and quality of land, in principle, without any change in the relationship of rights and duties of land (Cho, 2010).

The Housing Site Development Promotion Act, the Special Act on Public Housing and the Special Act on Private Rental Housing for creating urban housing complexes allow the expropriation method only, while the Urban Development Act allows both of the expropriation and replotting methods or the combined method. Therefore, the parks and green space ratio can differ depending on the land ownership processing method. Some earlier studies compared the expropriation and replotting methods in urban development projects. Shin (2005), Chung (2010) and Lee (2008) reported that expropriation was more advantageous from the perspective of securing infrastructure in case districts and inducing urban development, but did not compare and analyze the parks and green space ratio in detail. Kang (2008) and Ko (2010) analyzed the sensitivity of case districts to identify the advantages and disadvantages of each project type and their feasibility, but did not review the ratio of infrastructure sites such as parks, green space and roads. Meanwhile, Lee (2012) reviewed the average ratio of public facilities in previous urban development projects, and reported that the parks and green space ratio in the districts of expropriation was much higher. It was also found that the replotting districts showed a high ratio of roads due to their structure composed of detached small houses.

This study analyzed the land use plans of housing complex projects that have been executed since 2006 under the Urban Development Act, and factors that affect the urban parks and green space ratio depending on the land ownership processing method, and discussed the causes of differences in the green space ratio by city.

\section{Research Methods}

\section{Subjects}

In this study, residential complexes that have been established since 2006 were analyzed. According to the Statistics 
System of the Ministry of Land, Infrastructure and Transport (MOLIT), urban development projects are classified into 8 types including "residential," "industrial," "commercial” and "tourism." As of December 31, 2017, 344 out of a total of 452 districts across the country were "residential" projects, and their area was $113,142,000 \mathrm{~m}^{2}$, accounting for $74.7 \%$ of the total area (Table 1).

In 2005, the Act on Urban Parks, Green Areas, Etc. was enacted to establish standards to secure urban parks or green areas for various development projects. The Urban Development Act sets standards for urban parks and green areas depending on the area of development projects as follows: 10,000 $\mathrm{m}^{2} \sim 300,000 \mathrm{~m}^{2}, 300,000 \mathrm{~m}^{2} \sim 1,000,000 \mathrm{~m}^{2}, 1,000,000 \mathrm{~m}^{2}$ or bigger. In each case, the area of green areas is determined based on the residential population and development area of the target project district, and the larger of the two values is applied. For instance, when the development area is $1,000,000 \mathrm{~m}^{2}$ or bigger, the larger one between $9 \mathrm{~m}^{2}$ per resident and $12 \%$ of the development area is applied as the urban parks or green space.

Among these 344 "residential" urban development districts, 274 districts have been subject to the Act on Urban Parks, Green Areas, Etc. since 2006. Projects of which area is larger than 250,000 $\mathrm{m}^{2} \sim 300,000 \mathrm{~m}^{2}$ is subject to environmental impact evaluation (urban development projects), and, out of 274 development districts, 83 districts of which area to be developed was between $300,000 \mathrm{~m}^{2}$ and $1,000,000 \mathrm{~m}^{2}$ were selected in this study. Total area of the 83 districts was $47,636,000 \mathrm{~m}^{2}$ (Table 2).

Out of the 83 districts, a total of 61 districts were selected as the final subjects excluding the following 22 project districts: 14 districts that were not registered in the housing site information system of the Ministry of Ministry of Land, Infrastructure and Transport (MOLIT) and thus are difficult to analyze; 4 districts that were "residential" projects, but industrial, commercial and public cultural and sports facility sites accounted for over $40 \%$ of the total land use plan; 2

Table 1. Current status of urban development projects according to development type

\begin{tabular}{lccc}
\hline Development type & Zone & Development area $\left(1,000 \mathrm{~m}^{2}\right)$ & Percent $(\%)$ \\
\hline Public office buildings area & 3 & 350 & 0.2 \\
Public area & 1 & 155 & 0.1 \\
Tourism area & 10 & 3,578 & 2.4 \\
Complex area & 45 & 27,377 & 18.1 \\
Industrial area & 16 & 2,328 & 1.5 \\
Commercial area & 30 & 3,913 & 2.6 \\
Distribution area & 3 & 635 & 0.4 \\
Residential area & 344 & 113,142 & 74.7 \\
Total & 452 & 151,478 & 100.0 \\
\hline
\end{tabular}

Table 2. Housing-type urban development area project status (development planning district since 2006)

\begin{tabular}{lrcc}
\hline Development area & Zone & Development area $\left(1,000 \mathrm{~m}^{2}\right)$ & Percent $(\%)$ \\
\hline Less than $10,000 \mathrm{~m}^{2}$ & 1 & 10 & 0.01 \\
$10,000 \mathrm{~m}^{2} \sim 300,000 \mathrm{~m}^{2}$ & 179 & 20,074 & 23.02 \\
$300,000 \mathrm{~m}^{2} \sim 1,000,000 \mathrm{~m}^{2}$ & 83 & 47,636 & 54.63 \\
More than $1,000,000 \mathrm{~m}^{2}$ & 11 & 19,482 & 22.34 \\
Total & 274 & 87,201 & 100.00 \\
\hline
\end{tabular}


districts of which sum of land use items is over or lower than $100 \%$ due to overlapped decisions; and 2 districts to which both the expropriation and replotting methods were applied. In the case of which area was different from that shown in the Statistics System of the MOLIT, its data on the housing site information system of the MOLIT that listed the area of each land use item were used to calculate urban parks and green space ratio.

\section{Research and Analysis}

In order to analyze the components of land use plans for target urban development districts, the information on the land use plans for the urban development districts that had been notified on the housing site information system of the MOLIT by May, 2018 were utilized. Land use plan items on the housing site information system are divided into 4 steps as shown in Table 3. For instance, elementary school falls into the category of infrastructure site in the first step, public cultural and sports facility site in the second step and school in the third step, and is included one of 17 items in the fourth step including elementary, middle and high schools.

It was necessary to simplify the classified items in order to analyze their correlation with parks and green space ratio, and thus they were divided into residential sites (apartment house, detached house, semi-residential), commercial sites, infrastructure sites (parks and green areas, roads, public cultural and sports facilities, etc.) and industrial sites. Residential sites that were not classified in the four steps, but still remained as a residential site were classified as a semi-residential site after confirming whether they were classified as an apartment or a detached house. In this study, the parks and green space ratio $(\%)$ was the ratio of parks and green spaces (spaces or facilities that have green spaces such as urban parks,

Table 3. Land utilization plan items of housing site information system

\begin{tabular}{|c|c|c|c|}
\hline $\begin{array}{l}\text { Large category } \\
\quad(\text { step } 1)\end{array}$ & $\begin{array}{c}\text { Item } \\
(\text { Step 2) }\end{array}$ & $\begin{array}{l}\text { Details } \\
\text { (Step 3) }\end{array}$ & $\begin{array}{c}\text { Class } \\
(\text { Step 4) }\end{array}$ \\
\hline \multirow{7}{*}{ Residence sites } & \multirow[t]{3}{*}{ Apartment house site } & Apartment house & Apartment house, Apartment house etc \\
\hline & & Apartment & Apartment \\
\hline & & Row house & Row house \\
\hline & Detached house site & Detached house site & Detached house site, Detached house site etc \\
\hline & Residence site & Residence site & Residence site \\
\hline & \multirow[t]{2}{*}{ Quasi-Residential site } & Quasi-Residential site, & Quasi-Residential site, Quasi-Residential site etc \\
\hline & & Neighborhood living facilities site & Neighborhood living facilities \\
\hline Commercial sites & $\begin{array}{l}4 \text { items including } \\
\text { Commercial site, Business } \\
\text { facility site, etc }\end{array}$ & $\begin{array}{l}5 \text { items including Commercial site, } \\
\text { Business facility site, etc }\end{array}$ & $\begin{array}{l}7 \text { items including Commercial site, Business facility } \\
\text { site, etc }\end{array}$ \\
\hline \multirow{2}{*}{ Industrial sites } & Industrial site & Industrial site & Industrial site \\
\hline & Support facility site & Support facility site & Support facility site \\
\hline \multirow{7}{*}{ Infrastructure sites } & Open facilities site & $\begin{array}{l}\text { Public vacant land, Parks, Parks and } \\
\text { greenbelts, Squares, Green areas }\end{array}$ & $\begin{array}{l}17 \text { items including Public vacant land, Parks, Parks } \\
\text { and greenbelts, Squares, Green areas, Buffer } \\
\text { greenbelts, etc }\end{array}$ \\
\hline & Public cultural and sports & 8 items including Public office & \\
\hline & facilities site & buildings, Schools & $\begin{array}{l}17 \text { items including Public office buildings, Schools, } \\
\text { Cultural facilities, Sports facilities, etc }\end{array}$ \\
\hline & \multirow[t]{2}{*}{ Traffic facilities site } & Roads, Railroads, Parking lots, Bus & \\
\hline & & station & $\begin{array}{l}9 \text { items including Roads, Railroads, Parking lots, } \\
\text { Bus station, etc }\end{array}$ \\
\hline & 9 items including & 18 items including & \\
\hline & $\begin{array}{l}\text { Disaster-prevention } \\
\text { facilities, etc }\end{array}$ & Disaster-prevention facilities, etc & 26 items including Disaster-prevention facilities, etc \\
\hline
\end{tabular}


green areas, amusement parks, public open spaces and reservoirs and squares-pedestrian-only roads-rivers) to the development area that is defined by the Act on Urban Parks, Green Areas, Etc.

To analyze factors that affect the urban parks and green space ratio depending on the land ownership processing method, the subjects were divided into the districts of expropriation or replotting, and ratios between items on land use plans were compared. Causes of differences in the ratio of green areas between cities were analyzed by comparing the ratio of land use plans depending on the land ownership processing method within one region (city·county) and between different regions (city· county).

\section{Results and Discussion}

\section{Analysis of Land Use Plans}

Table 4 shows the results of analyzing the ratio of each item on the land use plans of 61 development districts by the land ownership processing method. In terms of the land ownership processing method, the number of development districts comprised of 12 expropriation and 49 replotting methods, respectively. Among land use items, apartments, parks and green areas, and roads accounted for about $73 \sim 76 \%$ of the total development area. The parks and green space ratio in expropriation district was $24.5 \%$, which is $7.7 \%$ higher than that of the replotting districts $(16.8 \%)$. The ratio of infrastructure sites including parks and green space in the expropriation districts was $53.1 \%$, which is $7.2 \%$ higher than $45.9 \%$ in the replotting districts. The replotting method showed a lower parks and green space ratio, but the ratio of roads is $22.1 \%$, which is 3.2\% higher than that in the expropriation districts(18.9\%). In addition, the ratio of residential sites including apartment house, detached house and semi-residental sites in the expropriation districts was $52.0 \%$, which is $10.7 \%$ higher than that in the replotting districts.

The reason why the replotting method shows the high ratio of roads is related to the high ratio of detached house or semi-residential sites in residential sites. When the ratio of detached house or semi-residental sites in residential sites is high, their unit lot is smaller than that of apartment house sites, and thus the ratio of roads is increased to segment the unit lot. When the ratio of apartment house sites is high, their unit lot is larger, and roads within apartment complexes are not included in calculating the ratio of public use land. In that case, the ratio of roads is reduced compared to other development projects of which the ratio of detached house sites is high (Ahn et al., 1996).

Table 4. Land utilization plan ratio of the research target districts

\begin{tabular}{|c|c|c|c|c|c|c|c|c|c|c|}
\hline \multirow{2}{*}{$\begin{array}{l}\text { Method of } \\
\text { Implementing } \\
\text { (Development } \\
\text { Zone) }\end{array}$} & \multicolumn{3}{|c|}{ Residence Sites (\%) } & \multirow[b]{2}{*}{$\begin{array}{l}\text { Commercial } \\
\text { Sites }(\%)\end{array}$} & \multicolumn{4}{|c|}{ Infrastructure Sites (\%) } & \multirow[b]{2}{*}{$\begin{array}{l}\text { Industrial } \\
\text { Site }(\%)\end{array}$} & \multirow[b]{2}{*}{ Total } \\
\hline & $\begin{array}{c}\text { (Apartment } \\
\text { House) }\end{array}$ & $\begin{array}{c}\text { (Detached } \\
\text { House) }\end{array}$ & $\begin{array}{c}\text { (Quasi- } \\
\text { Residential) }\end{array}$ & & $\begin{array}{c}\text { (Urban } \\
\text { Parks and } \\
\text { Green } \\
\text { Space) }\end{array}$ & (Roads) & $\begin{array}{c}\text { (Public } \\
\text { Cultural } \\
\text { Facilities) }\end{array}$ & Others & & \\
\hline $\begin{array}{l}\text { (A) Land } \\
\text { Expropriation } \\
\text { (12) }\end{array}$ & 32.2 & 6.1 & 3.0 & 5.4 & 24.5 & 18.9 & 5.8 & 3.9 & 0.2 & 100.0 \\
\hline $\begin{array}{l}\text { (B) Land } \\
\text { Replotting } \\
\text { (49) }\end{array}$ & 34.2 & 12.0 & 5.8 & 2.1 & 16.8 & 22.1 & 5.4 & 1.6 & 0.0 & 100.0 \\
\hline $\begin{array}{l}\text { Gap } \\
\text { (B-A) }\end{array}$ & 2.0 & 5.9 & 2.8 & -3.3 & -7.7 & 3.2 & -0.4 & -2.3 & -0.2 & \\
\hline
\end{tabular}


When the number of residents who prefer individual lots (detached houses, neighborhood living sites, etc.) is high, some part of apartment house sites needs to be converted into detached house sites. In this case, the area of roads is increased, and the ratio of other infrastructure sites, in particular, the ratio of parks and green areas, can be reduced due to the limited reduction rate of land compensation (50\%). For this reason, Jo (2009) compared expropriation and replotting methods after urban development projects are completed, and reported that the item that showed the highest difference in the satisfaction level of the projects was the satisfaction type of parks and green space, and that residents' satisfaction type of the residential environment that used the expropriation method was higher than the replotting method.

\section{Analysis of Parks and Green Space Ratio in the Same Region (City·County)}

Out of the 61 development districts analyzed in this study, there were 10 districts in 4 cities or counties where both the expropriation and replotting methods were implemented and thus land use plans were compared according to land ownership processing method, as shown in Table 5. There were 1 district that used the expropriation method, and 3 districts of replotting in Incheon. In Goyang, Dangjin and Gwanyang, there were one development districts where expropriation and replotting methods were implemented respectively.

The ratio of each land use plan item in the same city was analyzed by the land ownership processing method, as shown in Table 6. All the 4 districts in Incheon were executed by the private sector. The ratio of apartment house sites in a 3 districts of expropriation (41.9\% on average) was $35.0 \%, 44.0 \%$ and $46.7 \%$ respectively, and that in the district that used the replotting method was $46.6 \%$, higher than the average ratio of apartment house sites in the 12 districts of expropriation (32.2\%) and that in the 49 districts of the replotting method (34.2\%) as shown in Table 4. In Dangjin, those that used the expropriation method were executed by the public sector, and those that used the replotting method by the private sector.

Table 5. Status of development zone in the same city

\begin{tabular}{lcccc}
\hline Method of Implementing & Incheon & Dangjin & Gwangyang & Goyang \\
\hline Land Expropriation & 1 & 1 & 1 & 1 \\
Land Replotting & 3 & 1 & 2 & 1 \\
Total & 4 & 2 & 2 & 2 \\
\hline
\end{tabular}

Table 6. The present condition of land utilization plan ratio by the land ownership processing method in the same city

\begin{tabular}{|c|c|c|c|c|c|c|c|c|c|c|}
\hline \multirow[b]{2}{*}{ City } & \multirow[b]{2}{*}{$\begin{array}{l}\text { Method of } \\
\text { Implementing } \\
\text { (Development } \\
\text { Zone) }\end{array}$} & \multicolumn{3}{|c|}{ Residence Sites (\%) } & \multirow[b]{2}{*}{$\begin{array}{l}\text { Commercial } \\
\text { Sites } \\
(\%)\end{array}$} & \multicolumn{4}{|c|}{ Infrastructure Sites (\%) } & \multirow[b]{2}{*}{ Total } \\
\hline & & $\begin{array}{c}\text { (Apartment } \\
\text { House) }\end{array}$ & $\begin{array}{c}\text { (Detached } \\
\text { House) }\end{array}$ & $\begin{array}{c}\text { (Quasi- } \\
\text { Residential) }\end{array}$ & & $\begin{array}{l}\text { (Urban } \\
\text { Parks and } \\
\text { Green } \\
\text { Space) }\end{array}$ & (Roads) & $\begin{array}{c}\text { (Public } \\
\text { Cultural } \\
\text { Facilities) }\end{array}$ & Others & \\
\hline \multirow{2}{*}{ Incheon } & Expropriation(1) & 46.6 & 2.7 & 1.6 & 0.0 & 32.4 & 11.8 & 3.6 & 1.3 & 100.0 \\
\hline & Replotting(3) & 41.9 & 4.8 & 4.6 & 2.8 & 19.8 & 18.7 & 6.2 & 1.2 & 100.0 \\
\hline \multirow{2}{*}{ Dangjin } & Expropriation(1) & 21.4 & 4.4 & 5.7 & 2.6 & 22.3 & 25.2 & 16.8 & 1.6 & 100.0 \\
\hline & Replotting(1) & 24.5 & 9.6 & 9.6 & 3.3 & 18.4 & 27.1 & 6.2 & 1.3 & 100.0 \\
\hline \multirow{2}{*}{ Gwangyang } & Expropriation(1) & 47.7 & 1.7 & 2.8 & 3.5 & 19.3 & 16.0 & 7.4 & 1.5 & 100.0 \\
\hline & Replotting(1) & 19.6 & 19.5 & 9.4 & 0.0 & 19.8 & 26.2 & 4.3 & 1.2 & 100.0 \\
\hline \multirow{2}{*}{ Goyang } & Expropriation(1) & 35.2 & 4.4 & 1.6 & 16.5 & 15.2 & 20.8 & 3.9 & 2.2 & 100.0 \\
\hline & Replotting(1) & 48.6 & 0.7 & 3.0 & 2.8 & 17.5 & 18.0 & 8.4 & 1.0 & 100.0 \\
\hline
\end{tabular}


The ratio of apartment house sites in the districts of expropriation and replotting was $21.4 \%$ and $24.5 \%$ respectively, lower by over $10 \%$ than the overall average (32.2\% and $34.2 \%$ respectively), as shown in Table 4 . In those that used the expropriation method, the ratio of public cultural and sports facility sites including public offices such as city hall and education office was $16.8 \%$, higher than the average (5.8\%). In Gwangyang, those that used the expropriation method were also executed by the public sector, and those that used the replotting method by the private sector. The ratio of apartment house sites in the districts of replotting was 19.6\%, much lower than that in the districts of expropriation (47.7\%). In Goyang, those that used the expropriation method were also executed by the public sector, and those that used the replotting method by the private sector. The ratio of apartment house sites in the districts of expropriation was $35.2 \%$, lower than that in the districts of replotting (48.6\%), but the ratio of commercial sites including business building sites and multi-purpose building sites was $16.5 \%$, over three times higher than the average ratio of commercial sites in the 12 districts of expropriation (5.4\%).

In Incheon, parks and green space ratio in the expropriation districts was $32.4 \%$, and the ratio of infrastructure sites including parks and green space was $49.1 \%$, which were $12.6 \%$ and $3.2 \%$ higher than the parks and green space ratio $(19.8 \%)$ and the ratio of infrastructure sites (45.9\%) in the replotting districts. Meanwhile, the ratio of roads in the replotting districts was $18.7 \%$, which was $6.9 \%$ higher than that in the expropriation districts, which can be attributed to the higher ratio of detached house and semi-residential sites. The combined ratio of detached house and semi-residential sites in the replotting districts was by $5.1 \%$ higher than that in the expropriation districts.

In Dangjin, parks and green space ratio in the replotting districts was $18.4 \%$, lower than that in the expropriation districts $(22.3 \%)$. However, the ratio of roads in the replotting districts was $27.1 \%$, higher than the expropriation districts $(25.2 \%)$, which can be attributed to the higher ratio of detached house and semi-residential sites in the replotting districts compared to those of expropriation districts.

In Gwangyang, the parks and green space ratio and the ratio of roads in the replotting districts was $0.5 \%$ and $10.2 \%$ higher than the ratios in the expropriation districts. The reason why the ratio of roads in the replotting districts was high (26.2\%) can be attributed to the ratio of residential sites. The combined ratio of detached house and semi-residential sites of which unit lot is small was $28.9 \%$, which is by $9.3 \%$ higher than that of apartment house sites of which unit lot is large (19.6\%). Even though the average ratio of roads in the expropriation districts (16.0\%) is lower than that in the entire 12 expropriation districts (18.9\%), the parks and green space ratio (19.3\%) was lower than the overall average (24.5\%), which can be attributed to the result that the ratio of apartment house sites (47.7\%) was by $15.5 \%$ higher than the overall average in the entire expropriation districts (32.2\%).

In Goyang, the expropriation method showed a lower parks and green space ratio and a higher ratio of roads than the replotting method. The high ratio of roads can be attributed to the result that the ratio of commercial sites in the expropriation districts was $16.5 \%$, which was $11.1 \%$ higher than the average ratio of commercial sites in the entire 12 expropriation districts (5.4\%). Out of the ratio of commercial sites (16.5\%), business building sites accounted for 12.3\%, and the average area of sites was $6,623 \mathrm{~m}^{2}$, only $20.4 \%$ of the average area of apartment house sites $\left(32,487 \mathrm{~m}^{2}\right)$. That is, the ratio of detached house, semi-commercial and commercial sites (business building sites) of which unit lot is relatively small was high, which increased the ratio of roads, but decreased the parks and green space ratio. In the replotting districts, the ratio of roads was $18.0 \%$, which was lower than the average ratio of roads in the entire 49 replotting districts (22.1\%), but the ratio of apartment house sites $(48.6 \%)$, which was $14.4 \%$ higher than the overall average of the replotting method (34.2\%), resulted in the reduction in the parks and green space ratio (17.5\%).

When the ratio of apartment house sites is high, and that of parks and green space is low, the per capita ratio of parks and green space is decreased, reducing the quality of life from the perspective of utilizing parks and green space. Table 7 shows 
the results of comparing the per capita ratio of parks and green space in each district in Goyang. The parks and green space ratio in the replotting districts was higher than that in the expropriation districts, but the ratio of apartment house sites was $13.4 \%$ higher, and thus the per capita area of parks and green areas in the replotting districts $\left(7.4 \mathrm{~m}^{2}\right)$ was lower than the expropriation method $\left(7.7 \mathrm{~m}^{2}\right)$.

As discussed above, even though several development projects were operated in a city or county under the Urban Development Act, they showed different parks and green space ratios depending on the land ownership processing method. This can be attributed to the result that when the ratio of sites of which unit lot is small including detached house, semi-residential, commercial, public cultural and sports sites was high, the ratio of roads was increased together, and thus the parks and green space ratio was reduced. These results were observed in the replotting districts in Incheon, Gwangyang and Dangjin, and those that used the expropriation method in Goyang, and this has been pointed out as one of the problems observed in urban development projects that used the replotting method, and as a factor that reduces infrastructure and causes environmental problems in urban areas (Kim and Shin, 2012).

In order to improve the quality of life of residents, deviations in the parks and green space ratio need to be reduced, and urban parks need to be quantitatively expanded. To do so, it is necessary to develop and apply optimal indicators, to calculate optimal values through scientific empirical studies, and to review the range of the per capita area of urban parks (Kim et al., 2014), but it is very difficult to suggest an optimal level of green space in a city (Im and Kim, 2011). However, once case studies are sufficiently performed by the type of cities, it will be possible to suggest measures to introduce standards for the area and distribution of green space for each type of cities from the perspective of administration based on the results of case studies (Kim and Seong, 1993).

\section{Analysis of the Ratio of Parks and Green Areas Between Different Regions (City·County)}

The number of development districts by city and county and by the land ownership processing method of land is shown in Table 8. There were 6 cities that implemented over 3 projects including Gumi, Pohang, Incheon, Gimpo, Asan and

Table 7. A comparative study on the per capita green space of Goyang city according to the land ownership processing method

\begin{tabular}{lccccc}
\hline Method of Implementing & $\begin{array}{c}\text { Project Area } \\
\left(1,000 \mathrm{~m}^{2}\right)\end{array}$ & $\begin{array}{c}\text { Urban Parks and } \\
\text { Green Space Area } \\
\left(1,000 \mathrm{~m}^{2}\right)\end{array}$ & $\begin{array}{c}\text { Urban Parks and } \\
\text { Green Space Ratio } \\
(\%)\end{array}$ & $\begin{array}{c}\text { Plans for Admitting } \\
\text { the Population } \\
(\text { person })\end{array}$ & $\begin{array}{c}\text { Per Capita Urban Parks } \\
\text { and Green Space Area } \\
\left(\mathrm{m}^{2} / 1 \text { person }\right)\end{array}$ \\
\hline Land Expropriation & 646 & 98 & 15.2 & 12,711 & 7.7 \\
Land Replotting & 658 & 115 & 17.5 & 15,477 & 7.4 \\
\hline
\end{tabular}

Table 8. Status of development zone by city and county according to the land ownership processing method

\begin{tabular}{|c|c|c|c|c|c|c|}
\hline & 1 Project Zone & 2 Project Zone & 3 Project Zone & 4 Project Zone & 5 Project Zone & 7 Project Zone \\
\hline $\begin{array}{l}\text { Land } \\
\text { Expropriation }\end{array}$ & $\begin{array}{l}\text { Gwangju, Suwon, } \\
\text { Gimhae, Naju, } \\
\text { Wanju, Uiwang }\end{array}$ & $\begin{array}{c}\text { Gyeryong(2), Goyang(1), } \\
\text { Gwangyang(1), } \\
\text { Dangjin(1) }\end{array}$ & & Incheon(1) & & \\
\hline $\begin{array}{l}\text { Land } \\
\text { Replotting }\end{array}$ & $\begin{array}{l}\text { Gyeongju, Gwangmyeong, } \\
\text { Gunsan, Daejeon, Sacheon, } \\
\text { Seosan, Wonju, Yangsan, } \\
\text { Jeonju, Changwon, } \\
\text { Cheongju, Chilgok }\end{array}$ & $\begin{array}{l}\text { Yongin(2), Ulsan(2), } \\
\text { Jeju(2), Jinju(2) } \\
\text { Goyang(1), } \\
\text { Gwangyang(1), } \\
\text { Dangjin(1) }\end{array}$ & $\begin{array}{c}\text { Gumi(3) } \\
\text { Pohang(3) }\end{array}$ & Incheon(3) & $\begin{array}{c}\operatorname{Gimpo}(5) \\
\text { Asan(5) }\end{array}$ & Pyeongtaek(7) \\
\hline
\end{tabular}


Pyeongtaek, and all the districts in the cities, except 1 district in Incheon, adopted the replotting method, which can be attributed to one of its advantages that the method distributes an appropriate amount of profits to land owners, and, in turn, encourages land owners to positively participate in development projects (Park et al., 2007).

In order to compare the parks and green space ratio between different regions (city.county) depending on the land ownership processing method, the parks and green space ratio in the following cities were compared as shown in Table 9: Gyeryong, the only region that had more than 2 expropriation districts; and 3 cities that had more than 5 replotting districts including Gimpo, Asan and Pyeongtaek.

The area of one commercial site unit (distribution facility) in Gyeryong was 97,391 $\mathrm{m}^{2}$, three times larger than the average area of apartment house sites within the same district $(32,036 \mathrm{~m} 2)$, and thus it needed to be classified and analyzed as a site of which unit lot was large. Therefore, the combined ratio of detached house and semi-residential sites of which unit lot was small was $7.8 \%$, lower than the average ratio of the entire 12 expropriation districts $(9.1 \%)$. In turn, the ratio of roads $(14.3 \%)$ was lower than the average ratio of the 12 districts (18.9\%), but the parks and green space ratio (27.9\%) was higher than the average ratio $(24.5 \%)$.

The combined ratio of detached house and semi-residential sites of which unit lot was smaller than that of apartment house sites in Pyeongtaek and Asan was $12.8 \%$ and $18.9 \%$ respectively, lower than the average ratio of the replotting districts (19.9\%), while the parks and green space ratio was $17.7 \%$ and $18.8 \%$ respectively, higher than the average ratio $(16.8 \%)$.

The ratio of apartment house sites in Gimpo was 50.9\%, higher than the average ratio (34.2\%), and the combined ratio of detached house, semi-residential and commercial sites was $6.7 \%$, lower than the average ratio of the replotting districts $(19.9 \%)$. The ratio of roads $(16.7 \%)$ was lower than the average ratio $(22.1 \%)$, while the parks and green space ratio (20.2\%) was higher than the average ratio (16.8\%).

Compared to Gyeryong that applied the expropriation method, Pyeongtaek, Gimpo and Asan that developed sites that used the replotting method showed a lowparks and green space ratio. These results were commonly observed in cities and counties that used the replotting method in more than 2 districts. The replotting method used in urban development may reduce the width of roads and the parks and green space ratio, compared to the expropriation method, deteriorate locational conditions for various public urban facilities, thus reduce the overall quality of urban environment (Lee, 2005).

The optimal level of parks and green space for each city can be differently set according to various conditions of urban

Table 9. Current status of land utilization plan ratio by the land ownership processing method in different regions (city and county)

\begin{tabular}{|c|c|c|c|c|c|c|c|c|c|c|}
\hline \multirow[b]{2}{*}{ City } & \multirow[b]{2}{*}{$\begin{array}{l}\text { Method of } \\
\text { Implementing } \\
\text { (Development } \\
\text { Zone) }\end{array}$} & \multicolumn{3}{|c|}{ Residence Sites (\%) } & \multirow[b]{2}{*}{$\begin{array}{l}\text { Commercial } \\
\text { Sites } \\
(\%)\end{array}$} & \multicolumn{4}{|c|}{ Infrastructure Sites (\%) } & \multirow[b]{2}{*}{ Total } \\
\hline & & $\begin{array}{l}\text { (Apartment } \\
\text { House) }\end{array}$ & $\begin{array}{l}\text { (Detached } \\
\text { House) }\end{array}$ & $\begin{array}{c}\text { (Quasi- } \\
\text { Residential) }\end{array}$ & & $\begin{array}{l}\text { (Urban } \\
\text { Parks and } \\
\text { Green } \\
\text { Space ) }\end{array}$ & (Roads) & $\begin{array}{c}\text { (Public } \\
\text { Cultural } \\
\text { Facilities) }\end{array}$ & Others & \\
\hline Gyeryong & $\begin{array}{l}\text { Land Expropriation } \\
\text { (2) }\end{array}$ & 19.3 & 4.6 & 3.2 & 13.8 & 27.9 & 14.3 & 7.9 & 9.0 & 100.0 \\
\hline Pyeongtaek & $\begin{array}{l}\text { Land Replotting } \\
\text { (7) }\end{array}$ & 37.2 & 8.9 & 3.5 & 0.4 & 17.7 & 20.7 & 9.8 & 1.8 & 100.0 \\
\hline Gimpo & $\begin{array}{l}\text { Land Replotting } \\
\text { (5) }\end{array}$ & 50.9 & 2.6 & 3.0 & 1.1 & 20.2 & 16.7 & 4.4 & 1.1 & 100.0 \\
\hline Asan & $\begin{array}{l}\text { Land Replotting } \\
\text { (5) }\end{array}$ & 30.4 & 6.2 & 10.2 & 2.5 & 18.8 & 26.4 & 3.6 & 2.0 & 100.0 \\
\hline
\end{tabular}


areas such as the population intensity of cities, the distributed status of green areas surrounding cities, their accessibility, the size of towns, and the ecological value of green areas. However, parks are a universal service that the public can commonly enjoy as an important living infrastructure along with transport, culture and sports facilities, and it is necessary to approach this from a perspective of welfare, rather than considering efficiency, and thus to allow people to access and benefit in any region (Jo and Lee, 2014).

\section{Conclusion}

In this study, a total of 61 development districts built new residential complexes were selected, and their land use plans were analyzed to identify factors that caused the difference of urban parks and green space ratio depending on the land ownership processing method, and variations in the ratio of green areas in different cities or within a city. The ratio of parks and green space in districts that used expropriation and replotting methods was compared, and it was revealed that the ratio of parks and green space of expropriation districts was higher than that of replotting districts. Within a city or county as well, the ratio of parks and green space of the expropriation districts was also more than $10 \%$ higher compared to the replotting method. When the ratio was compared between different regions (city.county), the ration of parks and green space of the expropriation districts was higher than that of replotting districts. One of the reasons why the ratio of parks and green space of the replotting districts was lower than that of expropriation districts is related to the ratio of roads. When the ratio of sites of which unit lot was small (detached house, semi-residential, commercial, public cultural and sports facilities, etc.) was high in the replotting districts, the ratio of roads also increased, and thus the ratio of parks and green space decreased. Since both replotting and expropriation are presented as an implementation method in the Urban Development Act, it is not desirable to have a big difference in the ratio of parks and green space between the two methods. Therefore, it is recommended to secure an optimal level of parks and green space regardless of the implementation method in order to reduce such differences in the ratio of parks and green space between the implementing methods in urban development. It will be also necessary to improve standards for urban development, for instance by revising standards of the ratio of parks and green space, in order to prevent the parks and green space from being reduced depending on people's preference for detached house or semi-residential sites within a target district for urban development.

\section{References}

Ahn, K.H., H.S. Sakong, and Y.A. Lee. 1996. A study on the development density and land use in new town development. Anyang-si, Korea: Research Institute for Human Settlements.

Cho, S.H. 2010. A study on the appraisal method for urban development project by the replotting system: Focused on Young-in city. Master's thesis, Kangnam University, Yongin, Korea.

Chung, S.J. 2010. Comparisons of business method through case analysis of urban development project. Master's thesis, Gwangju University, Gwangju, Korea.

Im, Y.B. and C.H. Kim. 2011. A study on establishment standard of green space area in consideration of distribution of surrounding green land: Focused on second new town. J. Korea Plan. Assoc. 46(1):143-156.

Jo, J.R. 2009. An analysis of the degree of a residential environmental satisfaction by urban development project types. Master's thesis, Yonsei University, Seoul, Korea.

Jo, P.G. and S.W. Lee. 2014. A study on the improvement of living infrastructure for the public welfare. KRIHS Policy Brief No.456 (pp. 1-6). Sejong, Korea: Korea Research Institute for Human Settlements.

Kang, S.G. 2008. A comparative analysis of the feasibility of the urban development projects financed by private capitals. Master's thesis, Yonsei University, Seoul, Korea. 
Kim, G.G. and H.C. Seong. 1993. Studies on the optimum level and distribution of green spaces for new town development in the Seoul capital region. J. Korea Plan. Assoc. 28(1):69-79.

Kim, H., H.S. Choi, and E.B. Park. 2014. Study on urban park area calculation of USA and Japan. J. Urban Des. Inst. Korea: Urban Des. 15(6):47-60.

Kim, M.G. and D.J. Shin. 2012. A study on applicability of a different location replotting system for a land consolidation project. J. Korea Plan. Assoc. 47(3):393-408.

Ko, Y.S. 2010. A comparative analysis about the method of the urban development business. Master's thesis, Sejong University, Seoul, Korea.

Lee, J.M. 2008. A comparative of methods of urban development project. Master's thesis, Kangnam University, Yongin, Korea.

Lee, S.O. 2012. A study on comparing advantage of project methods of urban development. Master's thesis, Hanyang University, Seoul, Korea.

Lee, S.W. 2005. A comparative analysis on the land appropriation and readjustment mixed method of urban development. Master's thesis, University of Seoul, Seoul, Korea.

Moon, C.H. 2001. A study on the spatial characteristics of urban parks in Seoul through the analysis of decisive factors about degree of users' satisfaction. J. Geogr. Environ. Edu. 9(1):97-118. Retrieved from http://www.geoedu.or.kr

Park, S.W., S.W. Jeon, and H.Y. Park. 2007. Study on large-scaled public land development by introducing land provision compensation system. J. Urban Manage. 20(3):157-177. Retrieved from http://www.kruma.org

Shin, H.H. 2005. The comparison and analysis about the method of city development business. Master's thesis, Chung-Ang University, Seoul, Korea. 